\title{
PERSEPSI PENGEMBANGAN PETA RAWAN GEMPA KOTA SEMARANG MELALUI PENELITIAN HAZARD GEMPA DETERMINISTIK
}

\author{
Windu Partono*), Masyhur Irsyam, Sri Prabandiyani Retno Wardani, Syamsul Maarif \\ Jurusan Teknik Sipil, Fakultas Teknik, Universitas Diponegoro, \\ Jl. Prof. Soedarto, SH, Kampus Undip Tembalang, Semarang, Indonesia 50275
}

\begin{abstract}
Abstrak
Pengembangan peta resiko gempa berdasarkan analisa hazard gempa deterministik (DSHA) merupakan salah satu tahapan yang sangat penting untuk mitigasi kegempaan Kota Semarang. Penelitian peta resiko gempa mencakup perhitungan hazard gempa, analisa kondisi tanah lokal (SSA) dan analisa tingkat resiko kegempaan. Analisa hazard gempa diimplementasikan dengan pendekatan deterministic akibat gempa untuk sumber gempa sesar aktif disekitar Kota Semarang. Parameter geoteknik diperoleh dari hasil pengamatan atau pengujian geoteknik. Hasil dari penelitian ini mencakup pengembangan peta spektra percepatan gerakan tanah di permukaan dan faktor amplifikasi percepatan tanah yang sangat diperlukan pada pengembangan peta rawan gempa Kota Semarang.
\end{abstract}

Kata kunci: analisa hazard gempa deterministik; sesar aktif; spektra percepatan; faktor amplifikasi

\begin{abstract}
[Perception Development of Seismic Risk Map Semarang City Through Deterministic Hazard Analysis Research] Development of seismic risk map based on Deterministic Hazard Analysis (DSHA) is an important step for seismic disaster mitigation for Semarang City. The study includes estimation of seismic hazard (DSHA), site specific response analysis (SSA) and risk assessment. Seismic hazard is performed based on deterministic approach considering shallow crustal fault sources influencing Semarang City. Geotechnical parameters are interpreted from previous geotechnical measurements. The result of the hazard analysis includes the distribution of site response spectral acceleration and amplification ratios are performed corresponding to seismic risk assessment for Semarang City.
\end{abstract}

Keywords: deterministic hazard analysis; shallow crustal fault; response spectral acceleration; amplification ratio

\section{Pendahuluan}

Gambaran tentang tingkat kerawanan suatu daerah terhadap peristiwa gempa sering diimplementasikan dalam bentuk peta zonasi gempa (Seismic Hazard Map). Peta zonasi gempa memuat informasi tentang percepatan gerakan tanah di batuan dasar atau di permukaan. Badan Standarisasi Nasional (BSN) pada tahun 2012 telah menerbitkan peraturan tentang tata cara perencanaan ketahanan gempa untuk struktur bangunan gedung dan non gedung (SNI: 1726-2012). Pada peraturan tersebut juga disampaikan gambaran tentang tingkat kerawanan seluruh wilayah Indonesia terhadap peristiwa gempa.

Tingkat kerawanan wilayah Indonesia terhadap peristiwa gempa digambarkan dalam bentuk 3 peta gempa yaitu peta $\mathrm{MCE}_{\mathrm{R}}$ (gempa maksimum yang

\footnotetext{
${ }^{*}$ Penulis Korespondensi.

E-mail: windu_bapake_dila@yahoo.com
}

dipertimbangkan risiko-tertarget) untuk situs SB pada periode pendek dan panjang (SS dan S1) dan peta $\mathrm{MCE}_{\mathrm{G}}$ (gempa maksimum yang dipertimbangkan ratarata geometrik) untuk kelas situs SB. Peta-peta gempa sebagaimana tertuang pada SNI: 1726-2012 dapat memberikan gambaran tentang tingkat kerawanan suatu daerah terhadap peristiwa gempa. Tingkat kerawanan suatu daerah terhadap peristiwa gempa dapat dilihat dari besar kecilnya nilai percepatan gerakan tanah di batuan dasar atau di permukaan tanah. Untuk menghitung spektra percepatan di permukaan dapat dilakukan dengan mengalikan nilai $\mathrm{MCE}_{\mathrm{R}}$ maupun $\mathrm{MCE}_{\mathrm{G}}$ dengan faktor amplifikasi percepatan tanah.

Berdasarkan hasil penelitian yang telah dilakukan oleh Tim Revisi Peta Gempa Indonesia 2010, wilayah dengan lokasi berdekatan dengan sumber gempa sesar aktif sangat rawan terhadap peristiwa gempa. Kota Semarang merupakan kota dengan tingkat resiko gempa yang cukup tinggi, 
karena kota Semarang dikelilingi oleh beberapa sesar aktif. Sesar-sesar aktif yang berpotensi memberikan pengaruh cukup besar pada kota Semarang yaitu Sesar Opak (Yogyakarta), Sesar Lasem, Sesar Pati, Sesar Lembang dan Sesar Cimandiri. Sesar Lasem adalah salah satu sesar aktif yang posisinya sangat dekat dengan Kota Semarang dan bahkan jalur Sesar Lasem melewati Kota Semarang. Gambar 1 dan Gambar 2 menunjukkan posisi jalur Sesar Lasem terhadap Kota Semarang. Melihat tingkat resiko gempa yang cukup tinggi dan tingkat pembangunan infrastruktur yang semakin pesat, pengembangan peta seismic hazard dan peta rawan gempa kota Semarang menjadi sangat perlu untuk segera dilaksanakan.

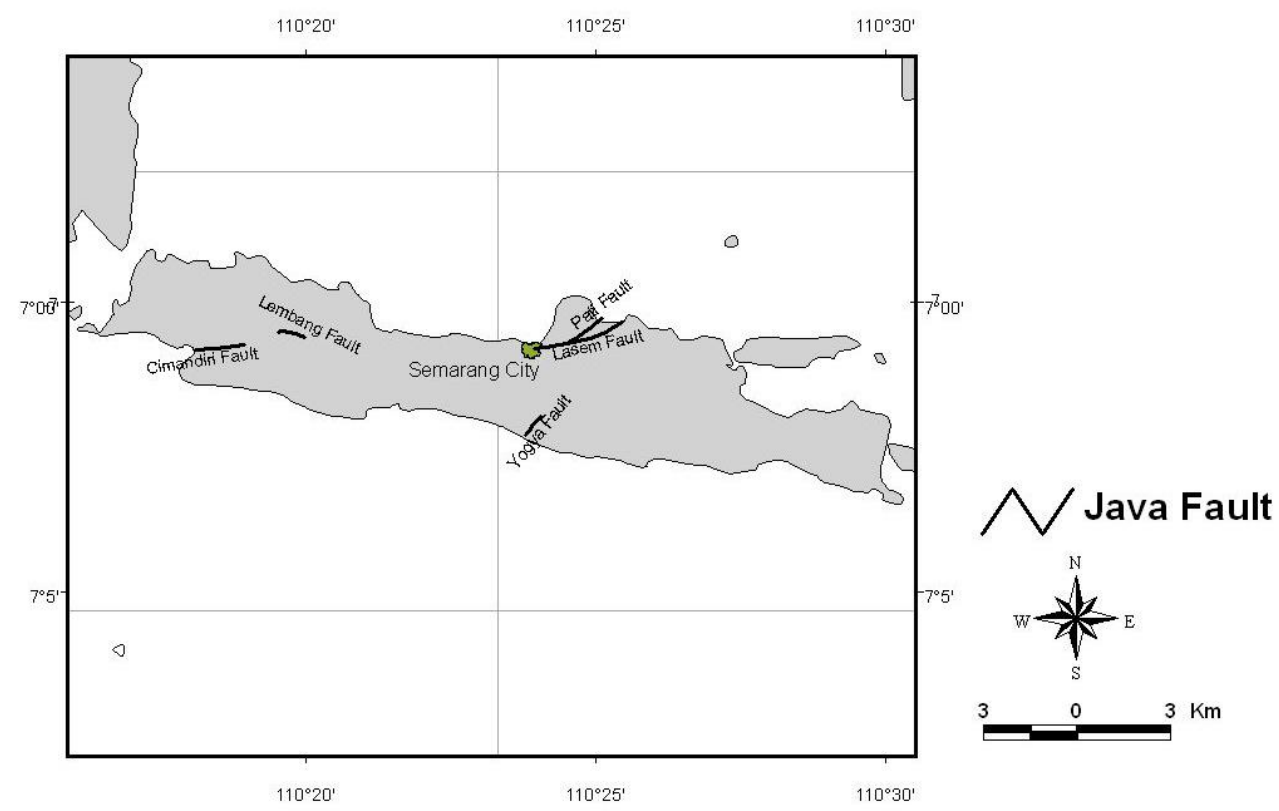

Gambar 1. Posisi Sesar Lasem Terhadap Kota Semarang

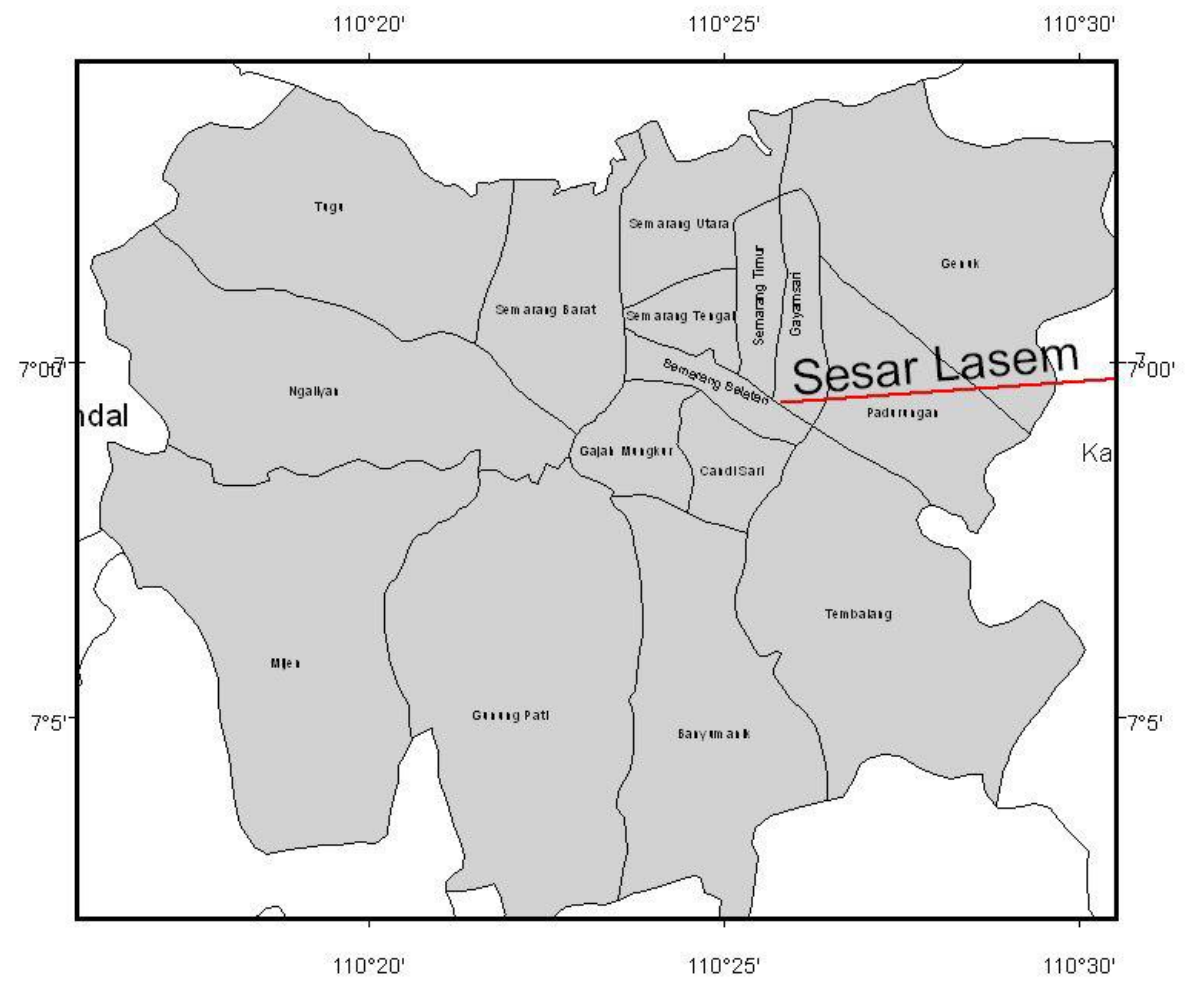

Gambar 2. Posisi Sesar Lasem Terhadap Kota Semarang 


\section{Teknik, 36 (1), 2015, 24-31}

Tujuan penelitian ini secara garis besar adalah (a) mengembangkan peta seismic hazard Kota Semarang untuk percepatan tanah puncak (Peak Ground Acceleration / PGA), spektra 0.2 detik dan 1 detik di batuan dasar dan di permukaan melalui pendekatan deterministik dengan menggunakan fungsi atenuasi, (b) membuat peta rawan gempa Kota Semarang melalui pendekatan deterministik dengan mengambangkan beberapa skenario kegempaan yang bersumber dari sumber gempa sesar aktif (shallow crustal fault).

\section{Metode Penelitian}

Analisa Seismic Hazard Deterministik (DSHA) banyak digunakan pada periode awal dari perhitungan seismic hazard. Konsep dasar DSHA adalah menentukan parameter ground motion dengan menggunakan magnituda gempa maksimum dan jarak sumber gempa yang paling dekat dari titik pengamatan (Kramer, 1996; Gupta, 2002; Baker, 2008; Irsyam, 2010). DSHA diimplementasikan dengan menentukan skenario parameter gempa dengan cara memilih magnituda maksimum dan lokasi terdekat dari sumber gempa yang diperkirakan akan menghasilkan dampak pada titik pengamatan. Secara umum metode pendekatan DSHA dapat dibagi menjadi 4 tahapan (Irsyam, 2010) yaitu: (1) melakukan identifikasi terhadap sumber-sumber gempa yang kemungkinan akan berpengaruh pada lokasi pengamatan, (2) menentukan skenario parameter gempa dengan cara memilih magnituda maksimum dan lokasi terdekat dari sumber gempa yang diperkirakan akan menghasilkan dampak pada lokasi pengamatan, (3) menentukan parameter gerakan tanah pada lokasi pengamatan dengan menggunakan fungsi atenuasi, dan (4) menentukan parameter gerakan tanah yang terbesar yang direncanakan akan terjadi pada lokasi pengamatan. DSHA dilakukan dengan menentukan parameter gerakan tanah pada lokasi pengamatan dengan menggunakan fungsi atenuasi. Pemilihan fungsi atenuasi sangat dipengaruhi oleh mekanisme kegempaan dari sumber gempa.

Pada penelitian ini analisa hazard gempa deterministik juga diimplememtasikan untuk Kota Semarang dengan menggunakan nilai VS30 $=760 \mathrm{~m} / \mathrm{s}$ (model 1) dan VS30 sesuai hasil penelitian pada lokasi pengamatan (model 2). Tiga spektra percepatan digunakan pada analisa dengan menggunakan model 1 yaitu untuk percepatan tanah puncak (PGA), periode 0.2 detik dan periode 1 detik. Pada penelitian ini jumlah titik pengamatan adalah 632 titik yang dibagi menjadi dua kelompok. Kelompok pertama terdiri dari 441 titik pengamatan yang disusun secara grid antara $110.2^{\circ}$ sampai $110.6^{\circ}$ longitude dan $-6.8^{\circ}$ sampai $-7.2^{\circ}$ latitude dengan interval grid $0.02^{\circ}$. Kelompok kedua terdiri dari 190 titik pengamatan yang mencerminkan lokasi titik pengeboran. Loksai titk pengamatan dapat dilihat pada Gambar 3 .

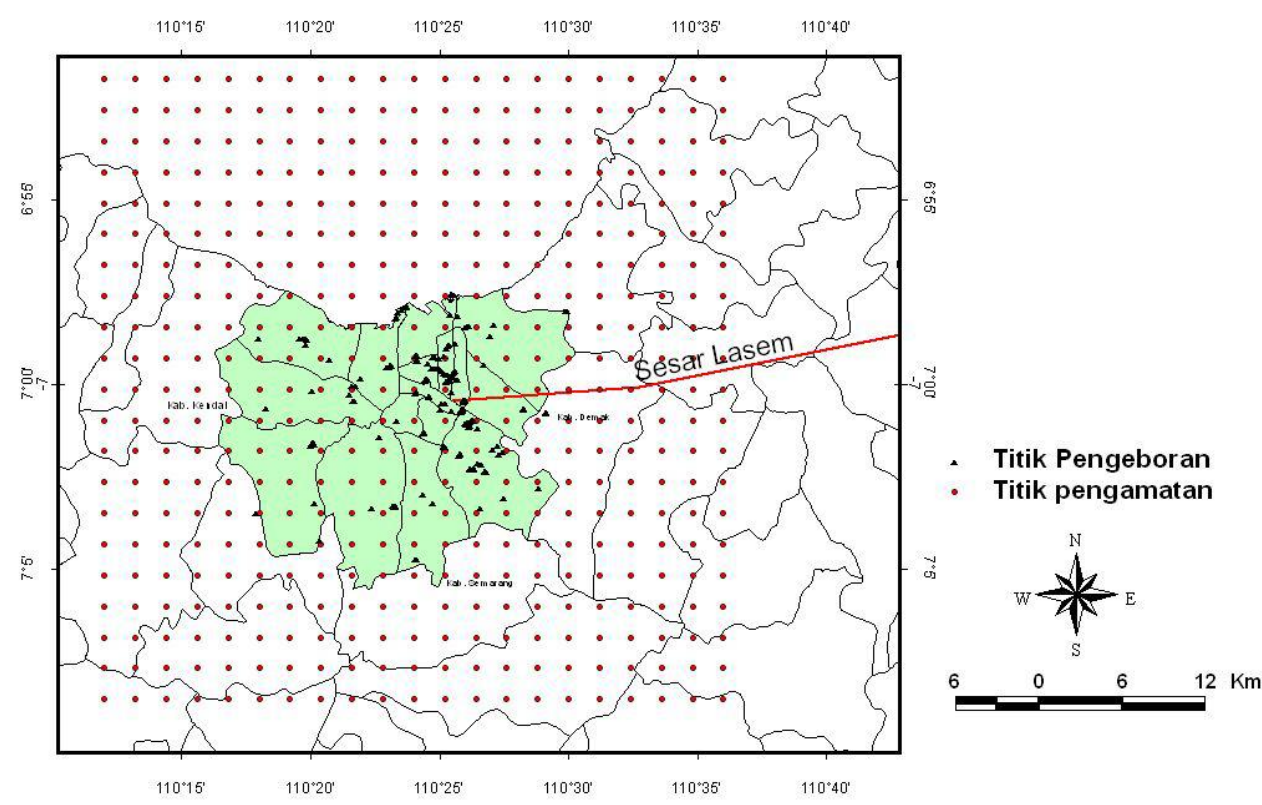

Gambar 3. Titik koordinat perhitungan Deterministik Hazard

Analisa deterministik hazard juga digunakan untuk mitigasi bencana gempa. Pada mitigasi bencana gempa maka telah diimplementasikan beberapa skenario kegempaan yang bersumber dari sumber gempa sesar Lasem. Pemilihan sumber gempa tersebut didasarkan pada jarak sumber gempa ke Kota Semarang. Pada analisa deterministik untuk mitigasi gempa telah dilakukan beberapa skenario kekuatan gempa. Dari hasil perhitungan spektra percepatan maka daerah rawan gempa untuk setiap skenario kegempaan dapat dipetakan. Pada analisa deterministik hazard untuk mitigasi gempa hanya ditinjau berapa kekuatan gempa untuk sumber gempa sesar Lasem dengan kekuatan minimum 6.5 Mw dan 
maksimum 7.2 Mw dan jarak titik pengamatan antara $5 \mathrm{Km}$ sampai $30 \mathrm{Km}$.

\section{Analisis Data Penelitian}

Pemilihan sumber gempa Sesar Lasem sebagai sumber gempa yang sangat berpengaruh pada Kota Semarang didasarkan pada hasil perhitungan PGA dari lima sumber gempa sesar aktif di sekitar wilayah Pulau Jawa sebagaimana terlihat pada Tabel 1. Pada Tabel 1 terlihat nilai minimum dan maksimum PGA, hasil analisa hazard deterministik pada elevasi batuan dasar dengan menerapkan model 1. Analisa hazard gempa deterministik akibat sumber gempa sesar Cimandiri menggunakan magnituda maksimum 7.2 Mw. Sumber gempa sesar Opak (Yogya) menggunakan magnituda maksimum 6.8 Mw. Untuk sumber gempa sesar Lembang, Pati dan Lasem masing-masing menggunakan magnituda maksimum 6.6 Mw, 6.8Mw dan 6.5 Mw.

Tabel 1. Nilai PGA untuk semua sumber gempa fault hasil analisa hazard deterministik dengan menggunakan nilai VS760

\begin{tabular}{|l|c|c|c|c|c|}
\hline Sumber Gempa & Sesar Lasem & Sesar Pati & Sesar Yogyakarta & Sesar Cimandiri & Sesar Lembang \\
\hline rata-rata (g) & 0.36 & 0.29 & 0.28 & 0.29 & 0.26 \\
\hline maximum (g) & 0.42 & 0.30 & 0.28 & 0.29 & 0.26 \\
\hline minimum (g) & 0.30 & 0.29 & 0.28 & 0.29 & 0.26 \\
\hline
\end{tabular}

Hasil analisa percepatan puncak (PGA) deterministik akibat sumber gempa sesar aktif menunjukkan goyangan gempa akibat sumber gempa Sesar Lasem paling dominan dibandingkan dengan sumber gempa yang lain. Gambar 4 menunjukkan distribusi nilai PGA di batuan dasar berdasarkan hasil analisa hazard gempa deterministik untuk model 1 akibat sumber gempa Sesar Lasem. Pada Gambar 4 terlihat wilayah timur Kota Semarang seperti Kecamatan Pedurungan, Kecamatan Gayamsari, Kecamatan Semarang Timur dan sebagian kecil wilayah Kecamatan Tembalang dan Kecamatan Genuk merupakan wilayah dengan nilai PGA terbesar untuk Kota Semarang.

Analisa hazard gempa deterministik juga diimplementasikan dengan menggunakan model 2 dengan tujuan untuk melihat seberapa besar perubahan nilai VS30 memberikan dampak terhadap hasil perhitungan deterministik hazard gempa. Nilai VS30 terkecil di Kota Semarang terletak di bagian utara Kota Semarang. Makin kecil nilai VS30 memberikan nilai spektra percepatan yang lebih tinggi. Hasil analisa hazard gempa deterministik untuk seluruh sumber gempa fault dapat dilihat pada Tabel 2. Hasil analisa hazard gempa deterministik sebagaimana terlihat pada Tabel 2 menunjukkan gempa akibat Sesar Lasem memberikan percepatan gerakan tanah yang lebih besar dibandingkan dengan sumber gempa lain. Distribusi hazard gempa deterministik dalam bentuk nilai PGA untuk model 2 dapat dilihat pada Gambar 5.

Tabel 2. Nilai PGA untuk semua sumber gempa fault hasil analisa hazard deterministik dengan menggunakan nilai VS30

\begin{tabular}{|l|c|c|c|c|c|}
\hline Sumber Gempa & Sesar Lasem & Sesar Pati & Sesar Yogyakarta & Sesar Cimandiri & Sesar Lembang \\
\hline rata-rata (g) & 0.37 & 0.30 & 0.28 & 0.28 & 0.26 \\
\hline maximum (g) & 0.46 & 0.32 & 0.31 & 0.31 & 0.28 \\
\hline minimum (g) & 0.25 & 0.22 & 0.20 & 0.20 & 0.19 \\
\hline
\end{tabular}

Gambar 4. Peta Hazard Gempa Deterministik Model 1 untuk PGA akibat sumber gempa Sesar Lasem dengan magnituda $6.5 \mathrm{Mw}$. 


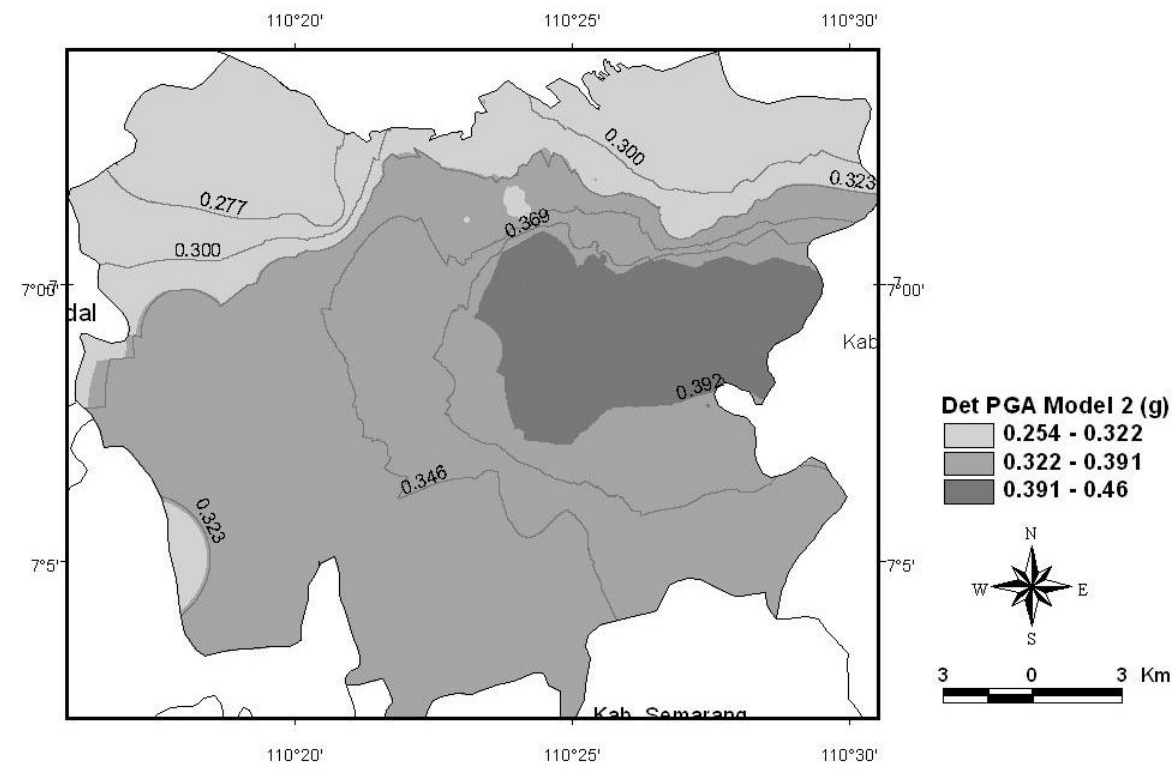

Gambar 5. Peta Hazard Gempa Deterministik Untuk PGA Untuk Model 2 Akibat Gempa Lasem Dengan Magnituda Rencana 6.5 Mw

Komparasi hasil analisa gempa hazard deterministik dengan menggunakan Model 1 dan Model 2 akibat sumber gempa Sesar Lasem dapat dilihat pada Tabel 3. Hasil perbandingan nilai PGA dengan menggunakan Model 2 secara rata-rata untuk seluruh titik pengamatan hampir sama dengan hasil perhitungan spektra percepatan untuk Model 1 . Perbedaan nilai PGA yang dihitung dengan menggunakan Model 2 dan Model 1 adalah sebesar 1.02. Dari hasil perbandingan nilai PGA dari kedua model tersebut, maka nilai faktor amplifikasi PGA rata-rata untuk Kota Semarang diperkirakan sebesar 1.02. SNI 1726-2012 menyampaikan untuk nilai PGA antara $0.3 \mathrm{~g}$ sampai $0.4 \mathrm{~g}$ maka faktor amplifikasi PGA berkisar antara 0.9 sampai 1.2 .

Tabel 3. Spektra percepatan deterministik untuk sumber gempa Sesar Lasem dengan menggunakan Model 1 dan Model 2

\begin{tabular}{|l|c|c|c|c|c|c|}
\hline & \multicolumn{3}{|c|}{ Model 1 } & \multicolumn{3}{c|}{ Model 2 } \\
\cline { 2 - 7 } & PGA & T= 0.2 s & T = 1s & PGA & T= 0.2 s & T = 1s \\
\hline rata-rata (g) & 0.36 & 0.83 & 0.22 & 0.37 & 0.75 & 0.40 \\
\hline maximum (g) & 0.42 & 0.95 & 0.25 & 0.46 & 0.96 & 0.47 \\
\hline minimum (g) & 0.30 & 0.69 & 0.18 & 0.25 & 0.44 & 0.30 \\
\hline
\end{tabular}

Analisa hazard gempa deterministik yang telah dilakukan untuk Kota Semarang belum melihat pengaruh dari kondisi tanah lokal dalam menghantarkan gelombang gempa atau gelombang geser dari batuan dasar ke permukaan. Peta rawan gempa suatu wilayah memerlukan analisa pengaruh dari lapisan tanah dalam merambatkan gelombang gempa ke permukaan. Untuk melihat pengaruh dari kondisi tanah lokal atau kondisi lapisan tanah dalam menghantarkan gelombang gempa dapat dilakukan dengan membuat skenario kegempaan akibat satu sumber gempa terhadap Kota Semarang. Skenario yang digunakan pada analisa hazard gempa deterministik dilakukan dengan memilih nilai magnituda gempa dan jarak sumber gempa ke titik pengamatan. Analisa rambatan gempa dari batuan dasar ke permukaan dilakukan dengan mimilih gelombang gempa dalam bentuk time histories yang dihasilkan dari peristiwa gempa yang memiliki mekanisme kegempaan yang sama dengan skenario kegempaan yang dipilih. Hasil analisa hazard gempa deterministik berbentuk peta PGA di permukaan dan peta faktor amplifikasi percepatan gerakan tanah.

Analisa hazard gempa deterministik dengan menggunakan skenario kegempaan tertentu yang diaplikasikan untuk Kota Semarang diimplementasikan dengan menggunakan sumber gempa shallow crustal fault dengan magnituda antara $6 \mathrm{Mw}$ sampai $7 \mathrm{Mw}$ dengan jarak sumber gempa antara $5 \mathrm{Km}$ sampai $30 \mathrm{Km}$. Ground motion atau time histories yang digunakan pada analisa hazard gempa deterministik Kota Semarang berasal dari empat peristiwa gempa Imperial Valley 1979, Morgan Hill 1984, Chifant Valley 1988 dan Duzce Turkey 1999. Pada analisa hazard gempa deterministik Kota Semarang dipilih dua belas (12) skenario kegempaan yang bersumber dari empat kejadian gempa dan dicatat pada beberapa station pengamatan sebagaimana terlihat pada Tabel 4.

Hasil analisa perambatan gelombang geser melalui dua belas skenario peristiwa gempa yang bersumber dari sesar aktif berbentuk peta distribusi 
PGA di permukaan dan faktor amplifikasi PGA. Peta distribusi nilai PGA di permukaan akan memberi gambaran tentang tempat-tempat yang akan mengalami guncangan yang besar di dalam wilayah Kota Semarang. Gambar 6 menunjukkan contoh hasil perhitungan distribusi nilai PGA di permukaan akibat skenario gempa 9. Hasil analisa deterministik untuk skenario 9 menunjukkan wilayah selatan Kota Semarang akan mengalami guncangan gempa terbesar jika terjadi gempa dengan kekuatan $6 \mathrm{Mw}$ sampai 7 Mw dengan jarak kurang dari $5 \mathrm{~km}$.

Tabel 4. Skenario Kegempaan Pada Analisa Deterministik Kota Semarang

\begin{tabular}{|c|c|c|c|c|c|}
\hline Skenario & Sumber Gempa & Mekanisme & Station & $\mathbf{M}$ & $R(\mathrm{Km})$ \\
\hline 1 & Morgan Hill 1984 & \multirow{12}{*}{ Strike Slip } & Hall Valley & 6.19 & 3.5 \\
\hline 2 & Morgan Hill 1984 & & Gilroy Array \#6 & 6.19 & 9.9 \\
\hline 3 & Chaifant Valley 1988 & & Benton & 6.19 & 21.9 \\
\hline 4 & Morgan Hill 1984 & & Freemont Mission San Jose & 6.19 & 31 \\
\hline 5 & Gempa Imperial Valey 10/15/1979 & & El Centro Differential Array & 6.53 & 5.1 \\
\hline 6 & Gempa Imperial Valey 10/15/1979 & & Brawly Airport & 6.53 & 10.4 \\
\hline 7 & Gempa Imperial Valey 10/15/1979 & & El Centro Array \#13 & 6.53 & 22 \\
\hline 8 & Gempa Imperial Valey 10/15/1979 & & Paster City & 6.53 & 30 \\
\hline 9 & Duzce Turkey 1999 & & Lemmont 1059 & 7.14 & 4.2 \\
\hline 10 & Duzce Turkey 1999 & & Lemmont 1062 & 7.14 & 9.2 \\
\hline 11 & Duzce Turkey 1999 & & Lemmont 362 & 7.14 & 23.4 \\
\hline 12 & Duzce Turkey 1999 & & Mudurmu & 7.14 & 34 \\
\hline
\end{tabular}

Jika dibandingkan dengan hasil analisa deterministik dengan menggunakan pendekatan fungsi atenuasi terlihat pola distribusi yang berbeda. Pola distribusi guncangan gempa dengan perhitungan fungsi atenuasi menunjukkan wilayah timur Kota Semarang mempunyai nilai PGA terbesar. Sedangkan dengan analisa rambatan gelombang gempa wilayah selatan mempunyai nilai PGA terbesar. Makin besar kekuatan gempa dan makin dekat jarak sumber gempa ke titik pengamatan akan mengakibatkan nilai PGA akan makin tinggi. Skenario kekuatan gempa 6.19 Mw, 6.53 Mw dan 7.14 Mw akan menyebabkan goyangan yang kuat untuk Kota Semarang jika sumber gempa terletak pada jarak maksimum $10 \mathrm{Km}$.

Hasil analisa hazard gempa deterministik untuk sumber gempa shallow crustal fault juga memberi gambaran tentang hubungan kekuatan gempa dan jarak sumber gempa dengan nilai faktor amplifikasi PGA. Untuk gempa dengan kekuatan makin membesar dan jarak sumber gempa makin dekat memberikan nilai faktor amplifikasi PGA makin kecil. Hasil analisa hazard gempa deterministik juga menunjukkan titik-titik pengamatan dengan nilai PGA permukaan makin besar memiliki nilai faktor amplifikasi PGA makin kecil. Tabel 5 menunjukkan nilai minimum, maximum dan rata-rata PGA permukaan dan faktor amplifikasi PGA hasil analisa dua belas skenario kegempaan. Pada Tabel 7 terlihat makin besar nilai magnituda gempa akan menyebabkan nilai faktor amplifikasi makin membesar. Gambar 6 menunjukkan distribusi nilai PGA akibat gempa untuk skenario 9.

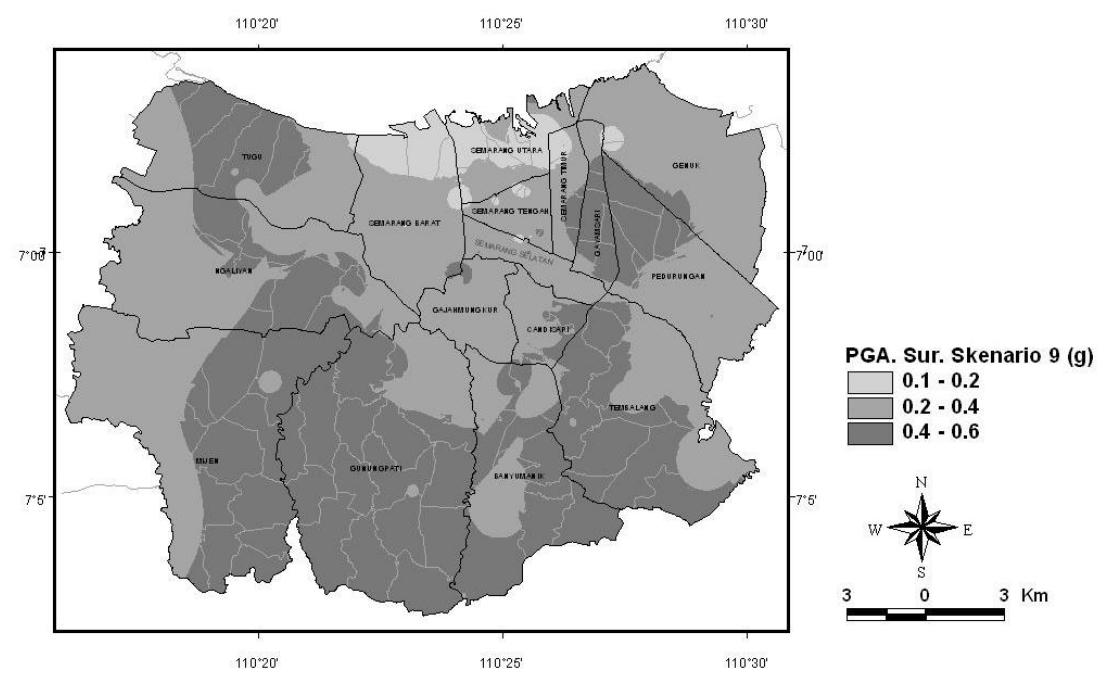

Gambar 6. PGA Di Permukaan Akibat Sumber Gempa Shallow Crustal Fault Dengan Magnituda 7.14 Mw dan Jarak 5 Km (Skenario 9) 
Tabel 5. Nilai Minimum, Maximum dan Rata-rata PGA Permukaan dan Faktor Amplifikasi Untuk Gempa Dengan Skenario 1, Skenario 5 dan Skenario 9

\begin{tabular}{|l|c|c|c|c|c|c|}
\hline & $\begin{array}{c}\text { PGA } \\
\text { Permukaan } \\
\text { Skenario 1 (g) }\end{array}$ & $\begin{array}{c}\text { Fak. } \\
\text { Amplifikasi } \\
\text { PGA Skenario } \\
\mathbf{1}\end{array}$ & $\begin{array}{c}\text { PGA } \\
\text { Permukaan } \\
\text { Skenario 5 (g) }\end{array}$ & $\begin{array}{c}\text { Fak. } \\
\text { Amplifikasi } \\
\text { PGA Skenario } \\
\mathbf{5}\end{array}$ & $\begin{array}{c}\text { PGA } \\
\text { Permukaan } \\
\text { Skenario 9 (g) }\end{array}$ & $\begin{array}{c}\text { Fak. } \\
\text { Amplifikasi } \\
\text { PGA Skenario } \\
\mathbf{9}\end{array}$ \\
\hline Minimum & 0.05 & 0.08 & 0.05 & 0.07 & 0.04 & 0.08 \\
\hline Maximum & 0.32 & 2.09 & 0.31 & 1.77 & 0.49 & 3.96 \\
\hline Rata-rata & 0.24 & 0.34 & 0.23 & 0.34 & 0.28 & 0.40 \\
\hline
\end{tabular}

Berdasarkan hasil perhitungan nilai PGA dipermukaan dengan pendekatan fungsi atenuasi sebagaimana terlihat pada Gambar 4 maupun Gambar 5 terlihat nilai PGA yang lebih kecil dibandingkan dengan hasil analisa skenario kegempaan sebagaimana terlihat pada Gambar 6. Hal ini menunjukkan wilayah selatan Kota Semarang akan diguncang gempa dengan sangat kuat jika terjadi gempa dengan kekuatan antara $6 \mathrm{Mw}$ sampai $7 \mathrm{Mw}$ dengan jarak sumber gempa kurang dari $10 \mathrm{Km}$. Hasil analisa perhitungan nilai PGA untuk skenario gempa yang lain menunjukkan wilayah Kota Semarang akan diguncang dengan guncangan yang lebih ringan jika terjadi gempa dengan kekuatan antara $6 \mathrm{Mw}$ sampai $7 \mathrm{Mw}$ dengan jarak sumber gempa lebih besar dari $10 \mathrm{Km}$.
Berdasarkan hasil analisa skenario kegempaan dengan kekuatan antara $6 \mathrm{Mw}$ sampai $7 \mathrm{Mw}$ dan jarak sumber gempa kurang dari $10 \mathrm{Km}$, maka dapat dikembangkan wilayah rawan gempa Kota Semarang. Pembagian wilayah rawan gempa tersebut didasarkan pada nilai minimum dan maksimum PGA akibat 12 skenario kegempaan. Wilayah gempa resiko rendah adalah wilayah yang akan menderita PGA kurang dari $0.2 \mathrm{~g}$. Wilayah resiko gempa sedang adalah wilayah dengan nilai PGA antara $0.2 \mathrm{~g}$ sampai $0.4 \mathrm{~g}$. Sedangkan wilayah resiko gempa tinggi adalah wilayah yang akan menderita nilai PGA antara $0.4 \mathrm{~g}$ sampai $0.6 \mathrm{~g}$ atau nilai PGA lebih dari 0.4g. Distribusi wilayah rawan gempa hasil analisa deterministik dapat dilihat pada Gambar 7.

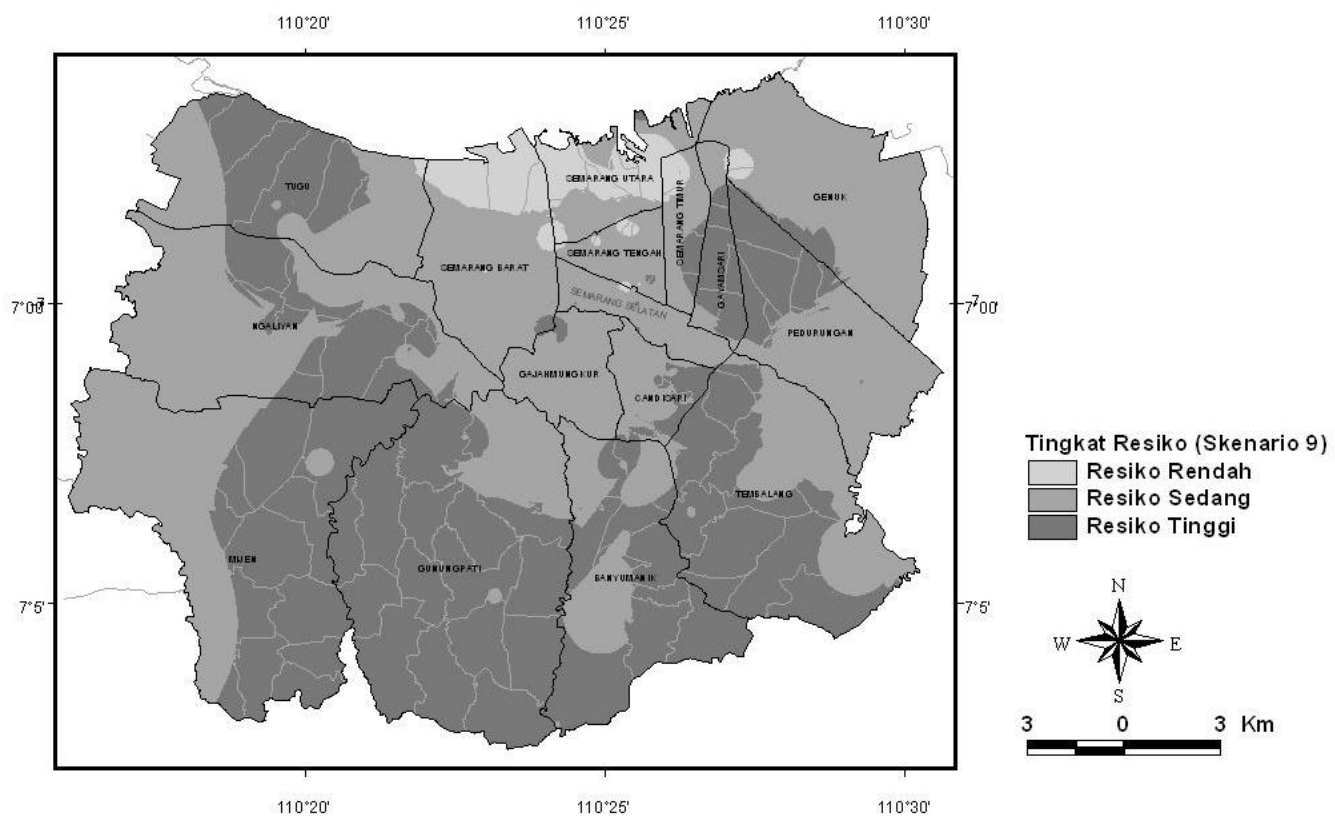

Gambar 7. Peta Wilayah rawan Gempa Kota Semarang Berdasarkan Perhitungan PGA Permukaan Akibat Skenario Gempa 9 (7.14 Mw dan Jarak Sumber 5 Km)

\section{Kesimpulan}

Penelitian daerah rawan gempa Kota Semarang dikembangkan berdasarkan hasil kajian Tim Revisi Peta Gempa Indonesia 2010 yang menyampaikan pentingnya mengkaji secara lebih detail tentang pengaruh Sesar Lasem terhadap tingkat kerawanan Kota Semarang dalam menahan guncangan gempa.
Penelitian daerah rawan gempa Kota Semarang dilakukan melalui tahapan analisa hazard gempa deterministik akibat semua sumber gempa yang berpotensi memberikan pengaruh yang besar pada Kota Semarang. Hasil kajian hazard gempa deterministik dipergunakan pada mitigasi gempa dan perencanaan bangunan tahan gempa di wilayah Kota 
Semarang. Besar kecilnya nilai PGA permukaan yang diperoleh dari hasil analisa hazard gempa deterministik memberi gambaran tentang kemampuan lapisan tanah dalam menahan guncangan maksimum akibat getaran gempa. Nilai PGA permukaan harus dievaluasi dengan analisa deterministik dengan mengembangkan skenario kegempaan untuk melihat distribusi guncangan tanah yang berpotensi terjadi pada setiap skenario kegempaan. Distribusi guncangan yang ditimbulkan pada setiap skenario kegempaan memberi gambaran tentang tingkat kerawanan Kota Semarang terhadap bahaya gempa. Kesimpulan yang dapat diperoleh dari hasil penelitian ini adalah:

1. Spektra percepatan yang telah diimplementasikan melalui peraturan gempa RSNI 03-1726-2002 memberikan nilai PGA permukaan yang tidak mampu menahan guncangan akibat gempa yang bersumber pada Sesar Lasem dengan kekuatan antara $6 \mathrm{Mw}$ sampai $7 \mathrm{Mw}$ dengan jarak sumber gempa kurang dari $30 \mathrm{Km}$.

2. Wilayah selatan Kota Semarang akan menderita guncangan terbesar dibandingkan wilayah tengah maupun utara Kota Semarang jika terjadi gempa dengan kekuatan antara $6 \mathrm{Mw}$ sampai $7 \mathrm{Mw}$ dan jarak gempa kurang dari $10 \mathrm{Km}$. Wilayah utara Kota Semarang merupakan wilayah yang menderita guncangan paling rendah akibat gempa dengan kekuatan $6 \mathrm{Mw}$ sampai $7 \mathrm{Mw}$.

\section{Daftar Pustaka}

Baker, J.W. (2008). An Introduction to Probability Seismic Hazard Analysis (PSHA). Version 1.3, October $1^{\text {st }}, 2008$.

Gupta, I.D. (2002). The State Of The Art In Seismic Hazard Analysis. ISET Journal of Earthquake Technology, Paper No. 428, Volume 39, No. 4, pp. 311-346.

Irsyam, M. (2010). Peran dan Pengembangan Rekayasa Geoteknik Kegempaan di Indonesia Dalam Pembangunan Infrastruktur Tahan Gempa, Pidato Ilmiah Guru Besar Institut Teknologi Bandung.

Kramer, S.L. (1996). Geotechnical Earthquake Engineering. Prentice Hall, Upper Saddle River, New Jersey 07458, xviii+653p.

SNI 1726 (2012). Tata Cara Perencanaan Ketahanan Gempa Untuk Struktur Bangunan Gedung dan Non Gedung, Badan Standardisasi Nasional, ICS 91.120.25:91.080.01. 